\title{
Corporate Disclosure: A Synthesis of Literature
}

\author{
Kennedy Prince Modugu, Ph.D. \\ College of Business \\ Higher Colleges of Technology, United Arab Emirates \\ E-mail: princekenny2010@gmail.com
}

Received: August 29, 2017 Accepted: September 11, $2017 \quad$ Published: July 24, 2018

doi:10.5296/ijafr.v8i3.11773

URL: https://doi.org/10.5296/ijafr.v8i3.11773

\begin{abstract}
This study is a compendium of the existing literature on corporate disclosure with a view to identifying the gaps to which future empirical inquiry may be directed. The paper discusses the concept of disclosure as canvassed by different authors. This review is initiated with a working definition of disclosure. This was followed by a series of reviews of studies in developed countries. Added to this, are developing countries' studies. The review showed that the influencers of corporate disclosure differ between developed and developing countries on the one hand, and within both economies on the other hand. The review revealed mixed findings on the determinants of corporate disclosure. This suggests that the factors determining corporate disclosure are not fixed, and vary from one jurisdiction to another. The paper also $\mathrm{x}$-rays a litany of theories of corporate disclosure research and suggests a unified theory that amalgamates the existing theories; and that which will be amenable to the ever-changing reporting environment.
\end{abstract}

Keywords: Corporate disclosure, Synthesis, Positive accounting, Agency, Stakeholders

\section{Introduction}

The economic contract between resource-owners and resource-managers provides that the latter should periodically be informed of the outcome of the activities of the former. This is done through several media, namely annual reports and accounts (as the principal window), bi-annual reports, monthly reports, newsletters and bulletins, internet reporting, as well as other pronouncement at conferences, seminars and symposia. Despite the satisfaction of this obligation by corporate managements, recent noisome events in some major companies across the globe suggest that a lot is left undone in corporate reporting. I am forced to ask whether corporate reporting simply connote the churning out of the mass volume of information that tells very little about the operations of a corporate entity or the fair 
presentation of relevant information that faithfully represents the effects of transactions undertaken by an entity over a defined period of time. I subscribe to the later. In the face of the unbroken yearly ritual of assembling shareholders at an annual general meeting to inform them about the activities of their companies, there still exists a broad lacuna between what is presented to shareholders and what actually happened. This has resulted in an increased clamour for more disclosure by stakeholders. What drives disclosure and what are the historical antecedents in corporate disclosure research? These, among other issues, are what this paper addresses.

The literature on corporate disclosure is replete with studies in both developed and emerging economies. In this article, the relationship between corporate characteristics and corporate disclosure is reviewed under two groups: developed countries and developing countries. As noted by Al-Zarouni (2008), the differences between previous studies are mainly based on sample size, the number of disclosure items, and the country of study. To avoid repetition, only some of the studies are reviewed.

\section{What Is Corporate Disclosure?}

Gibbins, Richardson and Waterhouse (1990) defined corporate disclosure as any deliberate release of financial (and non-financial) information, whether numerical or qualitative, required or voluntary, or via formal or informal channels. There are different means for companies to disclose information such as annual reports, conference calls, analyst presentations, investor relations, interim reports, prospectuses, press releases, websites, etc. The corporate annual report is considered a very important official disclosure vehicle, although on its own is not sufficient in the capital market context (Epstein \& Palepu; and 1999; Hope, 2003a), since other disclosure vehicles such as conference calls and interim reports can provide more timely disclosure. In addition, there are other sources of disclosure about companies' performance including, for example, financial analysts' reports and the press.

According to Grüning (2011), corporate disclosure is intended to provide information on the operating activities, and the financial and business situation of a firm to an interested audience. Firms' disclosure is therefore not limited to financial information but also addresses a great variety of non-financial information. It is undisputed that corporate disclosure increases the amount of information available to addressees. This information effect is only a means to an end and firms will hardly provide information out of philanthropic motives. In fact, it is purely economic reasoning that drives disclosure of corporate information

Hassan and Marston (2010) noted that disclosure is generally viewed as a latent variable, i.e., not amenable to be observed and measured directly. Therefore, we have to indirectly observe it through the values of an observed variable(s). In this respect, measures of disclosure can be reclassified into two approaches: the first approach tries to measure disclosure by reducing it to its observable characteristics in order to be able to measure it. The second approach tries to measure disclosure by identifying some observable variables that are assumed to have some relationship with disclosure. 
In this paper, disclosure is considered as the fair presentation of an entity's financial or non-financial information, be it mandatory or voluntary, and is useful to stakeholders' decision making. Fundamentally, for the information to be useful, it must be relevant and faithfully represents that which it purports to represent. In addition, the information is enhanced if it is comparable, verifiable, timely and understandable.

\section{Corporate Disclosures Studies in Developed Countries}

The pioneer study on accounting disclosure is Cerf (1961). Since then, a preponderance of research has been conducted on the subject in developed and developing countries alike. Each of these studies has been distinguished by the differences in the research setting, the differences in the definition of explanatory variables, differences in disclosure index construction and differences in statistical analysis (Umoren, 2009).

Cerf (1961) examines the level of disclosure in annual reports of US companies consisting of those listed on the New York Stock Exchange and other unlisted companies traded in over-the-counter (OTC) markets. Cerf investigated the relationship between four company variables (total assets, number of shareholders, profitability and listing status) and disclosure level. He developed a disclosure index based on 31 items of accounting information selected by a scale of 1 to 4 assigned to items in the interview with financial analysts. Using class means, Cerf revealed that a positive and significant relationship exists between asset size, profitability, and number of shareholders and disclosure level. Cerf also observed superiority of the companies listed on the NYSE over others. There was, however, no significant difference in the reporting pattern.

Singhvi and Desai (1971) is an improvement on Cerf (1961). It includes more variables with detailed and more rigorous empirical analysis. The duo of Singhvi and Desai (1971) examine the disclosure level and corporate attributes; comprising corporate size, profitability, listing status, auditor type, type of management and financial position. The study was carried out on a sample of 100 listed and 55 unlisted firms in the USA for the period between 1965 and 1966. A disclosure index of 34 items in the similitude of Cerf (1961) was used. The information items were assigned weights according to their relative importance as specified by committee members in corporate disclosure and security analysts. The author employed chi-square and a stepwise least squares regression technique in the empirical exercise and found that the entire six independent variables were statistically significant at $1 \%$, with listing status offering $87 \%$ of the explanatory power. They submitted that firms that disclose insufficient information have the tendency to be less profitable, small in size, free from the listing requirement, and audited by small CPA firms.

Moore and Buzby (1972) as cited in Sarpong (1999) challenge the works of Cerf (1961) and Singhvi and Desai (1971) from three standpoints; namely: the lack of details on assigning point score, the strict application of the dichotomous scoring procedure, and the failure to assess the multicollinearity between independent variables. A sample of 88 companies was used. Employing the weighted mean scores of the importance of information items, the quality of disclosure in percentage items was computed for each of the 88 companies. This was observed to be low. The findings further showed that information rated as important by 
financial analyst which include segmented sales and profit forecast, and 5 to 10 years historical summary were not adequately disclosed in the corporate reports.

A study by Choi (1973) investigates the relationship between accounting disclosure and international market entry by companies seeking external financing. A sample of 36 non-financial firms (comprising 18 companies listed on the Euro-capital market and matched group of 18 companies) from eleven countries was utilized. A disclosure index made up of 36 items of information was also used. The weighted and un-weighted score of the quantity of disclosure for each company were computed based on the disclosure in the annual reports. The Wilcoxon matched-pair signed-ranks test used revealed that there was a significant disclosure in companies listed on the Euro-capital market than the unlisted companies.

Buzby (1975) is a further inquiry at clarifying the conflicting findings of Cerf (1961) and Singhvi and Desai (1971). He investigated the relationship between disclosure extent and two firm attributes of asset size and listing status. A disclosure index was constructed from 39 information items selected from annual reports of 88 sample companies made up of 44 NYSE companies and 44 American Exchange (AMEX) companies. Wilcoxon matched-pairs sign-ranked test was carried out and the result revealed a low level of statistical significance between disclosure level and listing status. The Kendall rank correlation coefficient test showed a moderate positive association between the level of disclosure and asset size. This result is consistent with the work of Cerf (1961) and inconsistent with that of Singhvi and Desai (1971). A major limitation of Budzy (1975) is the measurement of disclosure from the information needs of analysts in the face of several other users of accounting information.

Barrett (1976) notices a steady improvement in disclosure from 1963 to 1972 in seven countries, comprising the United States, United Kingdom, France, Japan, Sweden, Netherlands and West Germany. Barrett's objective was to ascertain the superiority of UK and US companies in terms of disclosure to the other five countries. A sample of 15 companies was drawn from each country on the basis of market capitalization. Disclosure index was measured with 17 information items with 12 bearing semblances to prior studies. The findings show an insignificant difference in disclosure level between UK and US firms. He observed a significant difference between UK and US firms on the one hand and the remaining 5 firms on the other hand. He concluded that U.S. and U.K. firms disclose better. However, Umoren (2009) contend that British and American companies cannot be said to be pacesetters in accounting disclosures among the comity of nations. She maintains that Barrett's study indicated the extent and quality of disclosures in American firms which may not necessarily confer superiority of American accounting disclosure. This holds true because findings from Europe and America are not generalizable across continents.

In furtherance of the research sequence in disclosure in annual reports, Firth (1979a) investigates the degree of disclosure in British Stock Exchange companies. He used a list of 48 information items whose importance was weighted by financial analysts. A sample of 100 quoted manufacturing firms was drawn from the 1976 financial year. The result shows that segmented information is the most important to analysts. Forecast data were found to be moderately important while historical data received fairly high importance. Inflation-adjusted 
annual accounts as supplementary statements received a fairly high score. Overall, companies were observed to exhibit a weak level of disclosure. It was further observed that the British firms were strict observance of the provisions of the companies' acts and statements of accounting practice published by the Accounting Standards Committee.

As an improvement on Firth (1979a), Firth (1979b) studies the impact of size, listing status and auditing firm on voluntary disclosure in annual reports of UK firms. A sample of 180 companies was drawn and used for the study. The standard t-test and the Wilcoxon matched-pairs signed-ranks test were used and the results showed that only listing status had a positive relationship with disclosure. A positive association between capital employed as well as size and disclosure was shown by Kendall's rank correlation coefficient test.

A study on the quality of disclosure of financial and non-financial firms was carried out in New Zealand by McNally, Eng and Hasseldine (1982). The objective was to examine the association between quality of discretionary disclosure and size, rate of return, growth in assets, industry group and auditors. A structured questionnaire containing 41 discretionary items was administered each on New Zealand financial auditors and stock exchange members. A sample of 103 manufacturing firms for the 1979 financial year end was drawn to examine the degree of weighted items of information. Rank order correlations were carried out on assets size, rate of return and asset growth, while one -way ANOVA was used to test industry group and audit size. In all, only asset size was significantly related to disclosure quality.

Cooke (1989a) studies the relationship between disclosure level and corporate attributes of Swedish companies. A sample of 90 firms classified as unlisted, listed and multiple was drawn for the study. Cooke examined their aggregate, voluntary and responsibility disclosure levels to ascertain the impact of corporate characteristics on each of the components of corporate disclosure. Using a One-way ANOVA, the findings show that the trio of unlisted, single and multiple companies differ significantly for all disclosure components. Cook (1989a) is renowned for the following reasons: it decomposed the sample companies into 3; the complete set of the annual report not just financial statements formed the basis for disclosure index construction. In addition, no particular user-group was targeted in the determination of disclosure items as the range of items numbering 224 comprising financial and non-financial items were used (Umoren, 2009). Cooke (1989a) as cited in Umoren (2009) developed a score to capture the level of disclosure using a dichotomous procedure in which an item scores one disclosed and zero if not disclosed. Items not mentioned in the annual reports were presumed irrelevant and were not scored. The ratio of the actual score to total score formed the disclosure index. Using descriptive statistics to analyse the data obtained from the survey, the result revealed a significant degree of association between listing status and disclosure indices. Multivariate regression analysis was used to estimate which corporate quality determines the extent of disclosure. Out of the selected independent variables, the results showed that only listing status and size were major determinants of voluntary corporate disclosure. It was further observed that trading companies disclose less as compared to companies in other industries. On the contrary, multiple listed firms disclose more than single and domestically listed firms. 
Furtherance to Cooke (1989a), Cooke (1992) studies the impact of company size, stock market listing and industry type on total disclosure in Japanese companies. Cooke proxied company is size by a composite of capital stock, turnover, number of shareholders, total assets, current assets, shareholders' fund and bank borrowing. He used a list of 165 information items comprising 65\% voluntary and $35 \%$ mandatory items. Using the same technique of scoring as in Cooke (1989a), the results of the descriptive statistics showed a high average score for mandatory disclosure ranging from $88 \%$ to $100 \%$, with voluntary disclosure ranging from abysmally low $7 \%$ to moderately high $41 \%$. Results from the linear regression model revealed that manufacturing firms disclose a large amount of information than non-manufacturing firms. He concluded that company size, as well as industry type and multiple listing, encourages increased disclosure.

A study by Meek and Gray (1989) survey the level of compliance of continental European companies listed on the London Stock Exchange (LSE) with annual report disclosure requirements. Four countries consisting Sweden, the Netherlands, Germany and France were selected for the study. The sample consists of 28 non-financial companies with 14 Swedish, 7 Dutch, 4 German and 3 French firms for the year ended 31 December 1986 was examined. An un-weighted scoring technique was used to compute the disclosure score and the study revealed that the sampled companies the four countries surpassed the disclosure requirement of LSE for segment information disclosure.

Wallace, et al. (1994) surveying Spanish firms, examines the impact of corporate characteristics on disclosure in annual reports. A sample of 30 listed and 20 unlisted firms for the 1991 financial year was drawn. In proxying disclosure quality, the study constructed a comprehensive disclosure index of 16 mandatory items comprising both qualitative and quantitative items. They grouped the explanatory variables into three: structure-related variables (total assets, total sales, debt to equity ratio); market-related variables (industry type, listing status, auditor type) and performance-related variables (profitability, liquidity). Using the ranked ordinary least squares regression analysis, the result showed that only liquidity was negatively related to disclosure level. While size and listing status varied positively with disclosure index.

From the international perspective, Meek, Robert and Gray (1995) studied the factors that influence firms' disclosure quality in the UK, the US and Continental European multinational companies. The sample consists of 64 UK firms, 116 US firms, and 46 Continental European firms from France and the Netherlands. The sample relates to 1989 financial year and contains an equal number of domestically and internationally listed firms. The independent variables were listing, size, countries of origin, industry, leverage, multinationality and profitability. Using the regression analysis, they found significant variation in voluntary disclosure on an overall basis and by information type across countries. Out of the selected independent variables, size, country of origin and international listing status were the key determinants of voluntary disclosures. While listing status was a determinant of financial and strategic disclosures, it was not the case for non-financial disclosure. On the other hand, industry type showed a significant impact on financial and non-financial disclosures; but not 
strategic information. Multinationality, leverage and profitability showed no significant influence on voluntary disclosure.

A similar study to Meek et al (1995) was carried by Gray, Meek and Robert (1995). They sought to examine whether internationally listed UK and US companies voluntarily disclose more information than UK and US firms listed only on their respective stock exchanges. A sample of 58 US and 32 UK internationally listed firms with equal a number of domestically listed firms was drawn. A 128 item disclosure checklist made up of three groups; viz.: strategic information, non-financial information and financial information were constructed. The result derived from the Analysis of Variance (ANOVA) revealed that the US internationally listed firms disclosed a larger amount of strategic and non-financial information than the US domestically listed companies. There was no variation in the information disclosure between the UK internationally listed firms and their domestic counterparts.

The study by Inchausti (1997) examines the relationship between selected firm attributes and disclosure level of Spanish firms. This was a follow-up to Wallace et al (1994). The firm attributes selected were size, auditing firm, stock exchange listing, profitability, leverage, dividends and industry. A sample of 49 companies from 1989 to 1991 was drawn and used for the study. A combined disclosure index made up of 50 items of information was employed. The findings from the regression analysis showed that only size, auditing firms and stock exchange listing significantly impact accounting disclosure

Xiao (1999) examines the compliance level of Chinese firms with corporate disclosure requirements. A ten-item disclosure checklist from 10 firms was used. These information items consist of brief company introduction, a three-year summary of accounting and operation data, chairman's or managing director's statements, statement of material events, description of related companies, notice of annual general meeting, other information and reference information. No statistical tool was employed in the analysis of these items. However, the narratives showed that there appears to be a high level of compliance.

Hassan (2004) investigates the relationship between selected firm attributes and quality of disclosure in the annual accounts of Australian extractive industries from 1998 to 2001 . He constructed a disclosure checklist based on the Australian Accounting Standards Board (AASB) 1033. The firm attributes selected for this study are size, profitability, price-earnings ratio, market-to-book value, research and development activity, auditor, debt-to-equity ratios and type of extractive firm. The findings revealed that high-quality derivative information is value relevant. In addition, hedge information and risk information were observed to be as important to market participants in making informed decisions.

Iatridis (2008) investigates the association between company characteristics and accounting disclosure of UK companies. The disclosure issues examined were risk exposure, changes in accounting policies, use of international financial reporting standards and hedging practices. The findings showed that companies that provide informative accounting disclosures appear to display higher size, growth, profitability and leverage measures. Also, it was observed that the adoption of international financial reporting standards engenders consistency and 
reliability of financial reports, enhances the quality and the comparability of financial statements and also facilitates companies raising capital internationally.

Chen (2008) examines the disclosure of management cash flow forecast (a specific form of voluntary disclosure). The study investigates the relationship between discretionary accruals and managers' choice of whether to disclose cash flow forecasts with earnings forecasts. All the forecasts are from the year 1994 to 2003 because First Call only provides management cash flow forecasts information during that time period. The sample consists of companies that changed their forecast disclosure policies during the sample period. This sample consists of 2,697 firm-quarter observations relating to 112 companies during the years 1994 to 2003 . The study reveals a significant inverse relationship between discretionary accruals and the choice of issuing cash flow forecasts along with earnings forecasts. The result is consistent with the hypothesis that companies who issue both management earnings forecasts and cash flow forecasts would be more reluctant to manipulate earnings through discretionary accruals than companies who only issue management earnings forecasts. Similarly, in a time-series analysis, this study also finds a significant negative relationship between discretionary accruals and the choice of issuing both cash flow forecasts and earnings forecasts. The result supports the hypothesis that the discretionary accruals of the same company are lower at the time it issues both cash flow forecasts and earnings forecasts than at the time it only issues earnings forecasts.

$\mathrm{Lu}$ (2009) presents an empirical examination of whether disclosure of non-financial statement (NFS) information mitigates the under-investment problem, presumably by reducing information asymmetry between managers and potential stakeholders. The study focuses on one industry: the electronic equipment industry. The sample includes a balanced panel of 222 firms for the period from 2001 to 2003. The proxy for NFS disclosures is hand-collected from the sample firms' 2001 annual reports and the proxy for underinvestment is the cross-sectional variation in firms' investment level for the years 2002 and 2003. First, the researcher documents that managers who provide more NFS information are less likely to under-invest. Second, by classifying NFS disclosures into those that are more relevant to equity holders and those more relevant to debt holders, he finds that both types of disclosures are negatively associated with the degree of under-investment. Last, he also provides evidence that both equity- and debt-related NFS disclosures are positively associated with the level of subsequent equity financing. These results hold after the researcher uses a two-stage least squares (2SLS) specification to control for the endogeneity between investment and disclosure and that between equity financing and disclosure.

Lunawat (2010) looks at how financial disclosure enhances the building of trust and trustworthiness to facilitate institutions for exchange and investment in complex economic settings where there is a separation of ownership and control of key economic resources. Content analysis method was also adopted by the researcher. The research results show that the regime with disclosure allows for a greater time of mimicking with probability one and this additional reputation building opportunity results in higher probability of investment and a higher probability of high returns on investment. 
Popova, Georgakopoulos, Sotiropoulos and Vasileiou (2013) investigate the association between mandatory disclosure and company value expressed in share price anticipation of earnings by using a sample of 20 UK companies included in the FTSE 350 Index for a period of five years, from 2006 to 2010. A mandatory disclosure index was developed according to the IFRSs, which the companies listed in the stock market were obliged to adopt since 2005, and was utilized for the quantification of the extent of mandatory disclosure. The relationship between mandatory disclosure and some specific company characteristics was also investigated. The analysis revealed that, on average, the sample companies disclose information for the $91.51 \%$ of items required, indicating high compliance with the mandatory rules. This means that listed companies in the UK place a lot of emphasis on the IFRS disclosures, namely, the IASB help companies to become aware of the consequences of non-disclosure of adequate information in their annual reports. Moreover, the overall compliance with mandatory disclosure by UK companies is high compared to the companies of other countries. The study also revealed that companies gradually increased their level of disclosure since 2006, indicating that companies gradually develop their reporting practice and become more experienced in providing financial information for investors and other market participants. A significant association at 0.10 level was detected between company value and the extent of mandatory disclosure that is consistent with previous research. Additionally, it was found that leverage and age are significantly correlated with mandatory disclosure, while other company characteristics, such as earnings, size and listing status are not. These results are also consistent with previous researches. The findings support the regulation theory, which argues that regulation is a significant positive factor in the level of disclosure; therefore, disclosure should not rely solely on the market mechanism.

\section{Corporate Disclosure Studies in Developing Countries}

Just like in developed countries, several researchers have examined corporate disclosure in developing economies. Singhvi (1968) doctoral dissertation is about the first attempt at investigating the extent of corporate disclosure in emerging economies. He modifies Cerf's disclosure index and increased the independent variables to six. He examines a sample of 45 listed Indian firms. An index containing 34 items of information was created using assigned weights, ranging from 1 to 4 . The results of the Chi-square tests revealed that Indian firms vary in their corporate disclosure practices. Also, total assets, rate of return, earnings margin and type of management showed a significant direct relationship with company's disclosure quality.

Abdulsalam (1985) examines the association between selected firm characteristics and the extent of corporate disclosure. The study finds a negative relationship between firm size and corporate disclosure. However, the study fails to show clearly the relationship between growth, government subsidy, government ownership, audit firm size and corporate disclosure, thus opposed to the a priori expectation.

Chow and Wong-Boren (1987) examine the determinants of voluntary financial disclosures among Mexican firms. They tested the effect of three firm characteristics - firm size, financial leverage, and asset proportion. They sampled 52 manufacturing firms using the unweighted 
disclosure index method. 24 information items are used to construct the disclosure index. Using Pearson correlation and regression analysis, their study reveals that disclosure increases with firm size. No significant effect was observed for financial leverage and assets.

In Zimbabwe Owusu-Ansah (1998b) investigates the extent to which eight explanatory variables impact on corporate disclosure in 49 listed Zimbabwean firms. The study used an unweighted relative disclosure index method which consists of 32 disclosure items from the three regulatory sources in Zimbabwe (i.e., the adopted IAS, the Companies Act, and the listing rules of the ZSE). Using multivariate regression models, the study showed that company size, ownership structure, company age, multinational corporation alienation, and profitability have a statistically significant positive effect on mandatory disclosure while the quality of external audit, industry-type and liquidity were statistically insignificant. Similarly, Chamisa (2000) examines the compliance of listed Zimbabwean firms companies with the IASC standards. His results revealed high significance for both the compliance level and the impact of the IASC standards on the corporate reporting practices. He concludes that the IASC standards are relevant to Zimbabwe and similar capitalistic developing countries (Umoren, 2009)

In Bangladesh, Karim, Islam and Chowdhury (1998) examine the level of voluntary disclosure in 146 firms. 91 voluntary information items were used for the study. Using the unweighted index they find that the companies disclose an average of $26 \%$ of the 91 voluntary information items. The range is from 5 to 50. Also in Asia Akhtaruddin (2000) investigates the degree of mandatory disclosure by 94 firms listed both on the Dhaka Stock Exchange (DSE) and the Chittagong Stock Exchange (CSE). It further examines the relationship between company attributes, namely firm age, company size, listing status and profitability and mandatory disclosure. Unweighted disclosure index was used for the study. Using the OLS regression analysis, the results show that on the average companies disclose $44 \%$ of the items of information. Also, company age, profitability and status were found to have no significant effect on disclosure. However, industry size showed some influence on disclosure.

In Jordan, Naser and Karbhari (2002) investigate the disclosure practices of Jordanian companies following the adoption of International Accounting Standards (IAS). They examined the influence of firm characteristics on the depth of corporate disclosure using an unweighted disclosure index of 104 information items. A sample of 132 firms was used and the results revealed a fair improvement in the depth of disclosure following IAS adoption. A significant association was found between firm size, liquidity, profitability, gearing, audit firm status.

In Saudi Arabia, Naser and Nuseibeh (2003) examine the quality of disclosure of nonfinancial companies listed on the Saudi Stock Exchange. This study was a sequel to the introduction of a law permitting foreign investors into the Saudi capital market. "Central to this development is the annual reports published by companies operating in Saudi Arabia (Umoren, 2009 p.39)". The study used both weighted and unweighted indices comprising 23 items of mandatory information, 18 items of voluntary information related to mandatory 
information, and 14 items of voluntary information unrelated to mandatory disclosure. The results of the estimation exercise show a relatively high compliance with the mandatory requirements in all industries covered by the study, with the exception of the electricity sector. As for the voluntary disclosure, the analysis reveals that Saudi companies disclose information more than the minimum required by law. The level of voluntary disclosure, however, is relatively low.

In India, Ahmed (2005) examines the degree of voluntary reporting practices of listed non-financial companies with 12 disclosure items for 100 companies. He also relates the extent of voluntary reporting practices to industry type. An unweighted disclosure index was applied to the corporate annual reports for the year ending between June 30, 2002, and December 31, 2002. He finds that the level of reporting voluntary information items is low and the variability in the level of reporting among the companies is wide. Sector-wise comparison of voluntary reporting shows little fluctuations among the sectors that indicate a great deal of similarity among them in respect of reporting voluntary information items

In Egypt, Dahawy and Conover (2007) investigate the disclosures of the financial statements of listed companies in the Egyptian Stock Exchange. They use the disclosure checklist already designed by the Egyptian Capital Market Authority to measure compliance of the companies to disclosure requirement of the standards. The findings revealed that not all the companies comply fully with the international standard. The compliance rate is between $52 \%$ and $76 \%$ with an average disclosure level of $62 \%$. The lowest level of compliance is noticed for consolidated financial statements, leasing, and treatment of intangible assets. Their result is consistent with Street and Gray (2001) who find similar results for the countries studied.

Alkhatib (2014) examines the determinants of forward-looking information in Jordanian listed firms. To establish the factors that affect the disclosure, five company characteristics were employed, sector type (service sector and industrial sector), auditor type, total assets, profitability, and leverage. A sample of 125 companies listed on the Jordanian stock exchange for 2011 was used. Using the multivariate regression analysis, the study revealed that the profitability seems to be the most effective determinants of forward-looking information disclosure while the auditor type and the total assets found a significant impact on forward-looking information disclosure only in the industrial sector.

Madi, Ishak \& Manaf (2014) investigate the influence of audit committee characteristics (independence, financial expertise, size, frequency of meetings and directorship of AC members) on corporate voluntary disclosures of 146 Malaysian listed firms for the year 2009. Based on content analysis of disclosure, the empirical results of multiple regressions revealed that audit committee independence, size and multiple directorships of audit committee members are positively associated with corporate voluntary disclosure. The Frequency of meetings and financial expertise of audit committee members are not significantly associated with corporate voluntary disclosure.

Corporate disclosure studies have also been done in Nigeria. Wallace (1987) is reputed for pioneering corporate disclosure research in Nigeria. He examined the extent of disclosure using statutory and voluntary disclosure items. His choice of information items was relevant 
to the selected user groups used for the study which consists of accountants, top civil servants, managers, investors and other professionals. A sample of 47 firms, accounting for $54 \%$ of the entire companies quoted on the Nigerian Stock Exchange during 1982 and 1986 was used. Disclosure was treated as a dichotomous item, 1 for an item disclosed and 0 for those not disclosed. The scoring system is informed by its intensity. Both weighted and unweighted disclosure checklists were constructed. The weighted disclosure index reflects the preferences of the six-user groups. The result of the analysis revealed that companies which publish annual reports do not adequately comply with the disclosure regime. The overall disclosure index revealed the weakness in the disclosure practice in Nigeria, ranging from $37.55 \%$ to $43.11 \%$. A significant degree of disclosure was observed in the balance sheet, historical items, and valuation methods. However, status data, social reporting, income statement items and projections witnessed inadequate disclosure

Okike (2000) surveys the corporate reporting practices in Nigeria. The study sought to examine the adequacy of accounting disclosure in Nigeria. She concluded that accounting reports in Nigeria are weak and lacking in vital information, and thus, should be expanded to include a vast array of information useful for users' decision making. Also in Nigeria, Ofoegbu and Okoye (2006) investigating the relevance of accounting and auditing standards in corporate reporting in Nigeria sought to examine the degree to which selected Statement of Accounting Standards (SAS), namely SAS 3, 7, 8, 10, 11, 18 and 19 complied with in Nigeria. Using the annual reports of 41 quoted companies on the Nigerian Stock Exchange, the study revealed mixed results of compliance with disclosure requirements. For example, absolute compliance $(100 \%)$ was recorded for items such as the basis of determining book value of assets, cash flow presentations, disclosure of various forms of tax and movements of taxes and assets during the year. Partial compliance (ranging from 2\% to 90\%) was recorded for 93 items such as commission paid/received, maturity profile of risk asset of banks, frequency of revaluation policy and amount of foreign exchange gain or loss.

Kantudu (2006) explores the extent of compliance with requirements of SAS 2 by firms quoted on the Nigerian Stock Exchange. The study covered 16 sectors of the Nigerian economy out of which 25 companies were randomly selected for a period of 5 years (19982003). Data collected were analyzed using the qualitative grading system. The findings showed a significant compliance level with SAS 2 by the sampled company. This connotes that there was no significant difference between the disclosure requirement of SAS 2 and the content of the annual reports of the investigated firms.

Umoren (2009) investigates the level of compliance of financial and nonfinancial companies with the SAS disclosure and IFRS/IAS disclosure not contained in the SAS and the consequences of noncompliance with the disclosure requirements of SAS and IFRS/IAS by the Nigerian quoted companies. For SAS disclosure, while the results of the content analysis of the annual reports revealed that financial companies comply more that their nonfinancial counterparts, the independent sample t-test results showed that there is no significant difference in disclosure level for financial and nonfinancial listed companies. On the extent of compliance of listed financial and nonfinancial firms with the required disclosure of IAS/IFRS that are not contained in the SASs, the content analysis showed that financial 
companies comply more than the nonfinancial companies. Similarly, the result of the independent sample t-test revealed a significant level of disclosure between financial and non-financial firms with the former exhibiting more compliance level. "The compliance of the financial firms may be attributed to the growth in the capital base and global competition with fostered the application of relevant international accounting standards" (Umoren, 2009 p. 168).

Umoren (2009) also explores the relationship between firm attributes and corporate disclosure using company size, profitability, leverage, company age, industry type, size of audit firm, number of shareholders and multinational affiliation. Survey and content analysis methods were adopted in collecting the data used for the study. For the survey method, questionnaires were administered to a random sample of auditors, accountants and accounting information users (bankers, stockbrokers, financial analysts and educators) from the six geopolitical zones in Nigeria. For the content analysis, the extent of compliance by Nigerian listed companies was measured using the disclosure index of 90 listed companies. The companies were selected using the stratified random sampling. The findings of the study showed that only size, auditor type, and multinationality were significant positive determinants of overall corporate disclosure of companies.

Umoren and peace (2011) investigate the association between corporate governance, company attributes and voluntary disclosures among Nigerian listed companies. In order to examine this association, two disclosure indexes (weighted and unweighted) were built using a sample of 50 listed companies in Nigeria. The first index contains twenty items which are mandatory according to a number of selected IFRS but which are voluntary in Nigeria for the year 2008. The second index contains sixty voluntary accounting and non-accounting items. The study uses univariate, multivariate and cross-section models to explore the relationship between each disclosure index and corporate attributes. The corporate attributes are the independent variables comprising corporate governance and company characteristics. The results of the regression analysis revealed that only board size has a significant positive relationship with the extent of voluntary disclosures on the sample companies. The board composition, leverage, company size, profitability, and auditor type have a statistically positive and insignificant impact on disclosures. The effect of board ownership is positive for IFRS disclosures but negative and insignificant for Non-IFRS disclosures while the sector is negative for both disclosures and significant.

Uwuigbe, (2011) investigates the link between firm characteristics and the level of corporate social disclosures in the Nigerian financial sector. Using the judgmental sampling technique, a total of 31 listed firms have been selected for the study based on their level of market capitalization and direct financing of most firms from the manufacturing industry. Also, using the content analysis method, a scoring scheme is used for measuring the extent of corporate social disclosure in the annual report. Three variables were used in the study: firm's size, profitability, and size of the audit firm. The study observed that a positive association exists between a firm 's characteristics and the level of corporate social disclosure. In addition, the paper also observes that corporate social disclosures by listed firms are still in its infancy. 
Abdullahi (2012) examines the extent to which Nigerian Deposit Money Banks (DMBs) comply with the disclosure requirements of SAS 10 and to determine whether the NASB, Act 2003 enhances compliance with SAS 10. The study population is the then twenty-four (24) listed banks among which eleven (11) were selected. The study covers the period from 1998 to2002 and 2004 to 2008 with 2003 as the base year. And content analysis was used in collecting the data from the annual accounts of the selected banks. To test the hypothesis developed for the study, the researcher utilizes unweighted disclosure index. The result, however, reveals that the Nigerian DMBs do not adhere to the statutory disclosure requirements of SAS 10 but NASB act, 2003 enhances compliance with the said SAS.

Adekunle and Asaolu (2013) survey financial reporting practice among banks in the post-consolidation period. The sample size is the 13 listed Nigerian banks out of 21 registered banks in the period under examination. The researchers also develop composite disclosure Index (CDI) in collecting the data from annual accounts between 2005 and 2009 based on the statutory requirements of the SAS. Descriptive statistics and OLS were used in the analysis. The research results indicate a high level of compliance with the mandatory disclosure requirements for banks by scoring high on the CDI (mean in excess of 90\%). In addition, the regression results showed that disclosure has a positive and significant influence on banks stability (as defined by ROA and liquidity).

Ibrahim (2014) examines the extent of compliance of the Nigerian Deposit Money Banks with the disclosure requirements of accounting standards (SASs) for the year ended $31^{\text {st }}$ December 2011. In addition, the study further investigated the corporate attributes that determine the degree of disclosure by Nigerian Deposit Money Banks. A sample of 9 DMBs was selected and standards (SAS 2, 10 and 15 respectively) were utilized in the study. A researcher-developed checklist containing 34 information disclosure items (SAS 23 items and voluntary 11 items) was constructed. The corporate characteristics selected for the study are company size, leverage, profitability, auditor type, company age, and multinationality. Empirical findings from the content analysis of the annual reports of the tested banks revealed that there are strong and full compliance with the disclosure requirements of the SASs. The findings further showed that the selected DMBs do not disclose voluntary information. The study also revealed that there exists a significant association between the level of disclosure and some company characteristics. Corporate size and auditor type are found to be statistically significant determinants of corporate disclosure. While the other four variables of leverage, profitability, age, and multinationality are found to be statistically insignificant determinants of disclosure by the Nigerian DMBs.

\section{Theoretical Framework of Corporate Disclosure}

Currently, there exists no generally accepted theory of financial reporting or corporate disclosure (Umoren, 2009; Al-Shammari, 2005; Schipper, 2007). For several decades, empirical researchers have investigated accounting disclosure practices within the purview of different theoretical perspectives (Omran \& El-Galfy, 2014; Lopes \& Rodrigues, 2007). These theoretical perspectives fall within two approaches to the framework of financial reporting. They are the 'explain-predict' approach and the 'evaluate-develop' approach 
(Kiyanga, 2014; Coetzee, 2010). On the one hand, the 'explain-predict' approach consists of theories which attempt to predict and explain accounting practice rather than prescribing it. They include Agency Theory, Stakeholders Theory, Legitimacy Theory and Positive Accounting Theory. These theories dominate most of the prior empirical studies on corporate reporting. On the other hand, the 'evaluate-develop' approach is a prescriptive theory that prescribes a set of principles that are used to evaluate the existing accounting practice and also guide the development of new accounting standards and rules (Omran \& El-Galfy, 2014; Coetsee, 2010). This is the focus of the IASB Conceptual Framework. This present study, unlike previous studies, will be hinged on a combination of both approaches. This is because accounting, and by extension corporate disclosure is a social artifact which occurs within the context of social, economic and political interests, hence, it must be explained and predicted. In addition, corporate disclosure occurs within established principles and standards which guide preparers in the measuring and reporting of corporate information. Therefore, the adoption of a single approach to resolving the complexities associated with the definition, recognition, measurement and disclosure of corporate information and by extension, corporate disclosure research is not justifiable. The theories are discussed below.'

\subsection{The IASB Conceptual Framework}

Since 1970s several attempts have been made by professional accounting bodies and the academia to develop some form of more coherent conceptual framework. These efforts were only successful at country levels until IASB developed the first known general framework called the IASB Conceptual Framework for the Preparation and Presentation of Financial Statements (hereinafter known as The Conceptual Framework) which was first issued in 1989. The Conceptual Framework is a set of broad principles, definitions, assumptions and concepts that (a) provide a general frame of reference for evaluating accounting practices and (b) guide the development of new accounting practices. The primary focus of the Conceptual Framework is thus not to explain or predict accounting practice, but rather to guide the evaluation of existing practices and facilitate the development of new ones (Hendriksen, 1982; Wolk, Dodd \& Rozycki, 2008).

The most important goal of accounting theory is to provide a coherent set of principles for evaluating accounting practices and development of new accounting practice (Hendrinksen, 1982). The Conceptual Framework is committed to setting accounting standards which are principle-based rather than rule-based (Kiyanga, 2014). However, since there is currently no comprehensive theory of accounting, there is no empirical evidence in support of the Conceptual Framework supremacy over other theories of accounting (Kiyanga, 2014; Belkaoui, 2004; Coetsee, 2010)

There are inherent weaknesses in the Conceptual Framework, viz.: it describes accounting practices instead of explaining and predicting them. Besides, it does not take into account non-financial information. In addition, it insists on the historical cost basis of measurement. It has also been argued that the Conceptual Framework contains general statements that are refutable; lacks unity of purpose and fails to define boundaries within which standards setters should operate (Kiyanga, 2014). Some of these gaps were revealed by the IFRS Foundation 
in 2013 and addressed in the revised IASB Conceptual Framework of 2015. These shortcomings notwithstanding, The Conceptual Framework still remains relevant in corporate disclosure research.

\subsection{Positive Accounting Theory}

Prior to the mid-1960s accounting research was mainly normative, seeking to prescribe 'what should be' or 'what ought to be' in relation to accounting measurement and financial reporting. Normative accounting research failed to provide an empirical explanation of accounting practice (Omran \&El-Galfy, 2014). This led to the development of positive accounting research to combat this limitation. PAT came into existence in the 1960s from the work of Fama on the Efficient Market Hypothesis. It was later popularized by Gordon (1964) who posits that senior management was likely to manipulate the information in the financial statements in their own favour by selecting accounting procedures that maximize their own utility (Umoren, 2009). According to Watts and Zimmerman (1990), early studies that applied PAT are Ball and Brown (1968) and Beaver (1968). PAT is an accounting theory which seeks to explain and predict how choices of accounting standards, methods, and information disclosure formats are made (Watts \& Zimmerman, 1990). It is based on the assumptions that preparers act opportunistically in making accounting choices, contracting costing between an entity and its stakeholders influence the choice of accounting practices and that there is an explicit set of accounting choices to select from (Kiyanga, 2014).

Watts and Zimmerman (1986) highlight key hypotheses of PAT to include: the bonus plan hypothesis, debt/equity hypothesis and size hypothesis. The bonus plan hypothesis states that managers of entities with bonus plans are more likely to choose accounting procedures that shift reported earnings from future periods to the current period, other things being equal. The debt/equity hypothesis posits that the larger the debt/equity ratio the more likely the entity's manager is to select accounting procedures that shift earnings from future periods to the current period, other things being equal and the size hypothesis states the larger the entity the more likely managers are to choose accounting procedures that defer reported earnings from the current to future periods, other things being equal. Kiyanga (2014) observes that so far evidence from tests of the theory's hypotheses is consistent with the hypotheses, implying that the theory does explain and predict the choice of accounting practices.

However, Sternberg (1997) argues that the theory has several shortcomings. In the first place, it does not clarify whether the incentives for making accounting choices are economic, or efficient or social in nature. Secondly, the theory does not explain all accounting practices, as much remain unexplained. Thirdly, the implication in the theory that accounting choices are influenced by transactional costs only is not correct as there are other factors that influence the accounting choices made. For example, the nature of the entity, professional requirements, and industry practice may influence the choice of accounting practices (Gouws \&Cronje, 2008; Belkaoui, 2004). Lastly, the theory just focuses on the supply side of disclosure; the decision-making usefulness of the information disclosed does not feature as a factor influencing the choice. However, these shortcomings do not render the theory completely invalid. 


\section{Mll Macrothink}

International Journal of Accounting and Financial Reporting

ISSN 2162-3082

2018, Vol. 8, No. 3

PAT has a direct bearing on the research topic. In this study, corporate disclosure presents an excellent opportunity to apply PAT. This is premised on the fact that since managers (agents) have better access to companies' information, they can make a credible and reliable communication to the market to optimise the value of the firm. Through financial reporting, managers communicate to the users of financial reports, information that is useful in making choices among alternative uses of scarce resources. On the contrary, the managers may fail to make proper disclosure of useful information to the users due to their opportunistic tendencies. Such practices will not be in the best interests of shareholders (principal). Consequently, this may result in a higher cost of capital and lower value of shareholders' investments.

\subsection{Legitimacy Theory}

This theory seeks to explain an attempt by corporate entities to fight perceived threats to their legitimate rights (Kiyanga, 2014). The theory is based on the premise that there is an implied social contract between a corporate entity and society, and that the terms of the social contract specify the societal expectations from the corporate entity while at the same time defining the entity's operations, its growth, and survival (Guthrie \& Parker, 1989). The theory then suggests that a legitimacy gap arises when an entity is perceived to be failing to meet the societal expectations and that if the legitimacy gap is not narrowed then the entity begins to lose its legitimacy (Sethi, 1979). The legitimacy gaps may occur in the following circumstances. First, when there is a change in corporate performance, but the public expectations of corporate performance remain unchanged. Second, corporate performance remains the same but society expectations of corporate performance have changed. Third, corporate performance and society expectations of corporate performance have changed in a different direction, or in the same direction but with different momentum (Wartick \& Mahon, 1994). The evidence of loss of legitimacy may take different forms including revocation of the social contract and various sanctions including curtailment of access to some resources and even reduced demand for the entity's products. In extreme cases, the very existence of the entity may be threatened (Tilling, 2008).

Three strategies to narrow the legitimacy gap have been identified, namely, the legitimacy establishing strategy, the reactive strategy and legitimacy maintaining strategy (Khor, 2003). The strategy adopted by an entity depends on its circumstances (Dowling \& Pfeffer, 1975; Khor, 2003). New entities, on one hand, tend to adopt a legitimacy establishing strategy by complying with the terms of the social contract and disclosing the fact (Hearit, 1995). On the other hand, entities operating in a relatively stable environment tend to adopt a legitimacy maintaining strategy (Ashford \&Gibbs, 1990), while entities that are threatened by sanctions or closure tend to adopt a legitimacy defense strategy. Regarding the defensive strategy, two options have been identified. Either the entity changes its behaviour to comply with the new terms of the social contract or the perception of society towards the entity's behaviour is changed (Ashford \& Gibbs, 1990; Tilling, 2008).

In contrast to the Conceptual Framework, the Legitimacy Theory explains and predicts corporate disclosure from a preparer's perspective, as a tool by which entities communicate 
their legitimising strategies. The Legitimacy Theory holds that an entity's disclosure policies are influenced by its legitimising strategy. Accordingly, given an entity's legitimising strategy, one can deduce the type of corporate disclosure that achieves the strategy. This implies that disclosure levels between entities that face legitimacy crises could, other things being equal, be due to the differences in their legitimising strategies.

The validity of the Legitimacy Theory has been confirmed by studies of entity survival strategy during times of threat. It has been observed that whenever regulations, laws, standards or taste change, the entities that survive are those which adjust their behaviour to match the new situation (Ashford \&Gibbs, 1990). Entities that fail to narrow their legitimacy gaps succumb to sanctions and some fail to survive. However, although legitimacy theory is generally believed to explain corporate social disclosure and maintain that Legitimacy Theory can be rebutted or demonstrated depending on the association between disclosure and patterns and changes in societal opinions (Kiyanga, 2014).

The Legitimacy Theory is said to be one of the most cited theories in financial reporting and disclosure (Tilling, 2008). The areas in which the theory is applicable include; the accounting framework, social and environment accounting, sustainability reporting and the reporting of contingencies. For example, the theory validates the accounting framework by showing that stakeholders do influence financial disclosure. Concerning social and environmental disclosure, De Villiers and Van Staden, (2006) observed that legitimate objectives may be saved by changing the volume of environmental disclosure. Further to this, Brookhart, Beeler, and Culpepper (2005) observed that the issue of Staff Accounting Bulletin (SAB) 92 in the USA led to an increase in environmental disclosure in the Chemical and Petroleum industry; which is a reactive legitimacy strategy in terms of the Legitimacy Theory.

\subsection{Stakeholder Theory}

According to Kiyanga (2014), a stake is an interest in something. He posits further that a stakeholder is thus someone with an interest in something. Woodward (1993) describes stakeholders as comprising interest groups including human resources, owners, and non-equity suppliers of funds, suppliers of goods and services, customers, political groups, the general public as well as the physical environment. However, the concept 'stakeholder' has two meanings; the original but narrow concept of stakeholder and the widely used concept of stakeholder.

Originally, stakeholders meant those groups without whose support the entity would cease to exist (Freeman, 1994). This original but narrow meaning of the theory is practical because, to the extent that an entity depends on capital contributed by shareholders, the shareholders are the entity's stakeholders. Similarly, for an entity which depends on its employees' skills for survival, (a knowledge management entity) or an entity which depends on suppliers or customers for its survival, the employees, suppliers, and customers are its stakeholders (Kiyanga, 2014).

The widely used stakeholder concept views a stakeholder as any group or individual who can affect or be affected by the achievement of the organisation's objectives (Kiyanga, 2014). 


\section{Mll Macrothink}

International Journal of Accounting and Financial Reporting

ISSN 2162-3082

2018, Vol. 8, No. 3

This definition of stakeholder is so inclusive that every creature, human or otherwise, becomes a stakeholder including unborn children and terrorists (Freeman, 1994; Sternberg, 1997). Both concepts, however, are the basis of the Stakeholder Theory. The epicenter of the Stakeholder Theory is the doctrine that business should be run not for the financial benefits of their owners but for the benefit of all their stakeholders (Kiyanga, 2014). The essential tenets of the Stakeholder Theory are that organisations are accountable to their stakeholders, and the proper objective of management is to balance the stakeholders' conflicting interests. According to Camara, Chamorro and Moreno (2009) the Stakeholder Theory explains organisational responses to changing demands from constituents. However, the theory suffers from two major weaknesses. First, the inclusive definition of the term 'stakeholder' is not practical because an organisation cannot be accountable to an endless list of stakeholders. Second, the statement that the role of management is to balance the conflicting interests of various stakeholders is not attainable in business, given the countless business stakeholders and their conflicting interests (Sternberg, 1997).

Despite the perceived weaknesses, the Stakeholder Theory's philosophies have very useful applications in corporate reporting and disclosure. For example, its philosophy of accountability to stakeholders transcends beyond corporate information provision. The current business environment is making companies provide more detail information bothering on companies' interactions with the society in excess of the traditional financial statement. These include environmental reports, corporate governance reports, and social responsibility reports. Van der Laan (2009) asserts that this type of reporting provides evidence of how the Stakeholder Theory explains corporate disclosure. The Stakeholder Theory presents a strong justification for corporate disclosure because a stakeholder's interests in an organisation is predicated upon his knowledge about the organisation, and what is known about an organisation is a function of what is disclosed ceteris paribus.

\subsection{Agency Theory}

Agency Theory states that when one party (the principal) delegates decision-making powers to another party (the agent) under a contract, a principal-agent relationship arises (Jensen \&Meckling, 1976; Clarke, 2004). Jensen and Meckling define the principal-agent relationship as a contract under which one or more persons (principals) engages another person (the agent) to perform some services on their behalf, which involves giving some decision-making authority to the agent. Whereas the 'article of faith' in an agency arrangement is for both the principal and the agent to work towards the interest of the principal, information asymmetry and greed lure management into pursuing personal objectives instead of those of the principal. This conflict of interest or goal incongruence results in agency problem (Kiyanga, 2014; Fama \&Jensen, 1983; Clarke, 2004; Eisenhardt, 1989). From the business perspective, the agency relationship arises when shareholders (who are the owners of resources) delegate the administration of an entity to management (who administers the enterprise), thus making management the agent of the shareholders. In this kind of relationship, the expectation is that the agent (management) will pursue the shareholders' wealth maximisation objective (Kiyanga, 2014) 


\section{MlMacrothink}

International Journal of Accounting and Financial Reporting

ISSN 2162-3082

2018, Vol. 8, No. 3

The agency problems common in agency relationship include management's appropriation of bogus pay and sundry fringe benefits, management's involvement in risky investment projects, management's pursuit of personal objectives instead of those of the principal, or deliberate choice to operate sub-optimally (Gitman, 2009; Kiyanga, 2014).

Besides the shareholder-management relationship, an agency relationship may also be in the form of shareholder-lender relationship. This the shareholders do through management. Lenders entrust their money to shareholders, with the expectation that shareholders will honour the loan covenants agreed between the two parties. However, what may happen is that the shareholders, through management, may pay themselves excessive dividends or take on more loans contrary to the existing covenants with the lenders (Kiyanga, 2014; Gitman, 2009).

Two different but complementary versions of the Agency Theory exist in resolving the agency problem. They are the Positivist version and the principal-agent version (Kiyanga, 2014; Eisenhardt, 1989; Clarke, 2004). The Positivist version states that the agency problem can be solved by prescribing the appropriate governance mechanisms to limit the agent's opportunistic behaviour. The proponents of the Positivist Theory are more concerned with describing the mechanisms that solve the agency problem than with the various forms that the agency relationship may take or the optimal governance mechanism to apply (Jensen, 1983; Clarke, 2004). Positivists propose two alternative approaches to solving the agency problem depending on the extent to which the principal is able to observe the behaviour of the agent. When the behaviour of the agent is not observable this version of the Agency Theory recommends an outcome type of contract (Eisenhardt, 1989; Clarke, 2004). This is a contract in which the principal remunerates the agent on the basis of outcome. Eisenhardt (1989) argues that such a contract will automatically realign the agent's goals to those of the principal. Remuneration in the form of share options is an example of this type of outcome-based contract. Alternatively, the principal can invest in information systems such as budgeting, and corporate disclosure that motivates the agent to align his goals with those of the principal (Eisenhardt, 1989; Clarke, 2004).

On the other hand, the principal-agent version of the Agency Theory is concerned with the general theory of agent-principal relationships as well as with the best approach to solving the agency problem (Harris \&Raviv, 1979; Eisenhardt, 1989). It is general in that it can be applied in different forms of the principal-agent relationships including the customer-supplier, bank-customer and employee-employer relationships, and not just with the owner-management relationship as with the Positivist version (Eisenhardt, 1989; Clarke, 2004). Its approach to the agency problem involves determining the optimal contract between the principal and the agent depending on the extent to which the behaviour of the agent is observable (Clarke, 2004; Eisenhardt, 1989).

Therefore, when the behaviour of the agent is unobservable the principal - agent version of the Agency Theory proposes that the principal should either use an outcome-based contract or invest in information systems such as budgeting and disclosure that assist the principal in knowing what the agent is doing. On the other hand, where the principal does know what the 
agent is doing, the principal should use a behaviour-based contract to mitigate the agency problem (Clarke, 2004).

The two versions of the Agency Theory are complimentary in that they both prescribe investment in information systems as one of the solutions to the agency problem. From a financial reporting and accounting perspective, the Agency Theory explains and predicts accounting practice by citing the use of accounting practices to reduce information asymmetry, promote transparency and fight agency problems. Typical accounting rules and regulations that explain how the Agency Theory influences mandatory corporate disclosure include the disclosure of related party transactions, directors' remuneration, and auditors' remuneration.

The foregoing versions of the Agency Theory both prescribe that entities should invest in information systems to mitigate the agency conflict. From the standpoint of financial reporting and accounting, the Agency Theory explains and predicts accounting practices to stem the tide of information asymmetry, promote transparency and fight agency problems (Kiyanga, 2014). The Agency Theory is relevant to this study because the intended sample companies are those listed on the Nigerian Stock Exchange. The managements of these companies are separated from the owners (shareholders) and are required by the respective legal and regulatory authorities to render the account of stewardship to the shareholders at the annual general meetings. In fulfilling this obligation, managements employ the accounting standards and rules to disclose information to the shareholders.

Also, Ibrahim (2014) argues that Agency Theory has a direct nexus with corporate disclosure research because corporate disclosure presents an ample opportunity to apply positive agency theory. This is due to the fact that managers (agents), by the nature of their position in the firm, have better access to company's accounting information and ceteris paribus can make a timely, reliable and credible communication to the market to optimise the value of the firm. Through financial reporting, they communicate to the users of financial reports information that is useful in making an informed economic decision among alternative uses of scarce resources. On the contrary, these managers may, because of their selfish interests, fail to make proper disclosure or fail to disclose important information to the users, thereby leading to information asymmetry. Such practices will not be in the best interests of shareholders (principal). Consequently, this may result in a higher cost of capital and lower value of shareholders' investments.

\section{Conclusion}

In the preceding sections, I have X-rayed the historical antecedents of corporate disclosure research from developed economies to developing economies. The foregoing reveals that discussions on corporate disclosure cannot be dispensed with, as long as corporations maintain their going-concern status. Instead, corporate disclosure will continue to experience a paradigm shift as witnessed in recent years with the advent of sustainability reporting and integrated reporting. Therefore, management must device newer means to adequately and qualitatively render their accounts of stewardship to stakeholders in the face of the ever-dynamic business environment; with a view to satisfying the increasing demand for 
more information by diverse stakeholders. Corporate managers must not only be accountable and transparent, they must be seen to be so. Through this, the capital markets will become more efficient and investors' confidence can be earned.

Although the theories discussed above have formed the theoretical underpinning for prior studies in corporate disclosure, there is the need for a comprehensive and generally accepted accounting theory that will synthesize the individual theories into a consolidated theory of disclosure. The new theory will not only guide the existing and development of new accounting practices but would also explain and predict accounting practice. Thus, this would help in amalgamating the schools of thought into a unified theory of disclosure. Whereas such a theory may not help in completely obliterating the inherent challenges in corporate reporting occasioned by the dynamics in the reporting environment, it will surely help set the stage towards the alignment of the proposed unified theory with changes in the business environment as they occur.

\section{References}

Abdulsalam, M. (1985). General disclosure requirements and measuring its existence in the Saudi corporate annual reports. College of Management Science Research Center, King Saud University, Riyadh.

Adekunle, A., \& Asaolu, T. (2013). An empirical investigation of the financial reporting practices and banks' stability in Nigeria. Kuwait Chapter of Arabian Journal of Business and Management Review, 2(5), 34-40.

Ahmed, H. (2005). Corporate voluntary reporting practices in India. The Cost and Management, 33(5), 73-79.

Akhtaruddin, M., \& Haron, H. (2010). Board ownership, audit committees' effectiveness, and corporate voluntary disclosures. Asian Review of Accounting, 18(3), 245-259.

Al-Shammari, B. (2005). Compliance with international accounting standards by listed companies in the gulf co-operation council member states: An empirical study (Unpublished Doctoral Dissertation).University of Western Australia, Perth.

Al-Zarouni, A. (2008). Corporate Financial Disclosure in Emerging Markets: The case of the UAE. Doctoral Dissertation, Griffith University, U.K. Retrieved from https://www120.secure.griffith.edu.au/.../Al-Zarouni_2009_02Thesis

Ashford, B.E., \& Gibbs, B.W. (1990). The double-edge of organizational legitimation. Organization Science, 1(2), 177-194.

Ball, R., \& Brown, P. (1968). An empirical evaluation of accounting income numbers. Journal of Accounting Research, 6(2), 59-178.

Barrett, M.E. (1976). Financial reporting practices: Disclosure and comprehensiveness in an international setting. Journal of Accounting Research, 14(1), 10-26. 


\section{$\triangle 1$ Macrothink}

International Journal of Accounting and Financial Reporting

ISSN 2162-3082 2018, Vol. 8, No. 3

Beaver, W. (1968). The information content of annual earnings announcements. Journal of Accounting Research, 6, 67-92.

Belkaoui, R.A. (2004). Accounting Theory. London: Thomson Learning.

Brookhart, J.M., Beeler, J.D., \& Culpepper, D. (2005). Regulatory guidance, legitimacy theory and environmental disclosure. Journal of Accounting \& Finance Research, 13(2), 1-8.

Buzby, S. L. (1975). Company size, listed versus unlisted stocks, and the extent of financial disclosure. Journal of Accounting Research, 13(1), 16-37.

Camara, M., Chamorro, E., \& Moreno, A. (2009). Stakeholder reporting: the Spanish tobacco monopoly, 1887-1986. European Accounting Review, 18(4), 697-717.

Cerf, A. R. (1961). Corporate Reporting and Investment Decisions. Berkeley: University of California Press.

Chamisa, E.E. (2000). The relevance and observance of the IASC Standards in developing countries and the particular case of Zimbabwe. The International Journal of Accounting, $35(2), 267-286$.

Chandra, G. (1974). A study of the consensus of disclosure among public accountants and security analysts. Accounting Review, 49(4), 733-42.

Chen, H. (2008). Management earnings forecasts, cash flow forecasts and earnings management, (Unpublished Doctoral Thesis). Arizona State University, USA

Choi, F.D.S. (1973). Financial disclosure and entry to the European capital market. Journal of Accounting Research, 11(2), 159-175.

Chow, C. W., \& Wong-Boren, A. (1987). Voluntary financial disclosure by Mexican corporations. The Accounting Review, 62(3), 533-541.

Clarke, T. (Ed.). (2004). Theories of corporate governance: The philosophical foundations of corporate governance. London: Routledge.

Coetsee, D. (2010). The role of accounting theory in the development of accounting principles. Meditari Accountancy Research, 18(1), 1-16.

Coleman, A.K., Adjasi C.K., \& Abor, J. (2007). Corporate governance and firm performance: evidence from Ghanaian listed companies. Corporate Ownership and Control, 4(2), 123-132.

Cooke, T.E. (1989a). Disclosure in the corporate annual reports of Swedish companies. Accounting and Business Research, 19(74), 113-124.

Cooke, T.E. (1992). The impact of size, stock market listing and industry type on disclosure in the annual reports of Japanese listed corporations. Accounting and Business Research, 22(87), 229-237.

Dahawy, K., \& Conover, T. (2007). Accounting disclosure in companies listed on the Egyptian stock exchange. Middle East Finance and Economics, 1, 1-20. 
De Villiers, C., \& Van Staden, C.J. (2006). Can less environmental disclosure have a legitimising effect? Evidence from Africa. Accounting Organisations and Society, 31(8), 763-781.

Dowling, J.J., \& Pfeffer, J. (1975). Organisational legitimacy: Social values and organisational behaviour. Pacific Sociological Review, 18(3), 122-136.

Eisenhardt, K. M. (1989). Agency theory: An assessment and review. Academy of Management Review, 14(1), 57-74.

Fama, E. F., \& Jensen, M. C. (1983). Separation of ownership and control. Journal of Law and Economics, 26(3), 301-325.

Firth, M. (1979a). The disclosure of information by companies. Omega, 7(2), 129-135.

Firth, M. (1979b). The impact of size, stock market listing and auditors on voluntary disclosure in corporate annual reports. Accounting and Business Research, 939, Autumn, 273-280.

Freeman, R.E. (1994). The politics of stakeholder theory. Business Ethics Quart, 4(4), 409-421.

Gibbins, M., Richardson, A., \& Waterhouse, J. (1990). The management of corporate financial disclosure: opportunism, ritualism, policies, and processes. Journal of Accounting Research, 28(1), 121-143.

Gordon, M. (1964). Postulates, principles and research in accounting. The Accounting Review, $39(2), 251-263$.

Gouws, D.G., \& Cronje, C.J. (2008). Corporate annual reports: accounting practices in transition. South African Business Review, 12(2), 108-133.

Gray, S. J., Meek, G. K., \& Roberts, C. B. (1995).International capital market pressures and voluntary annual report disclosures by U.S. and U.K. multinationals. Journal of International Financial Management and Accounting, 6(1), 43-68

Guthrie, J., \& Parker, L.D. (1989). Corporate social reporting: A rebuttal of legitimacy theory. Accounting and Business Research, 19(76), 242-252.

Harris, M., \& Raviv, A. (1979). Some results on incentive contracts with applications to education and employment, health, insurance and law enforcement. America Economic Review, 68, 20-30.

Hassan, M. S. (2004). The information quality of derivative disclosure in the corporate annual reports of Australian firms in the extractive industries. Unpublished Doctoral Thesis, Queensland University of Technology.

Healy, P. M., \& Palepu, K. G. (2001). Information asymmetry, corporate disclosure, and the capital markets: A review of the empirical disclosure literature. Journal of Accounting and Economics, 31(1-3), 405-440. 


\section{Ml Macrothink}

International Journal of Accounting and Financial Reporting

ISSN 2162-3082

2018, Vol. 8, No. 3

Hearit, K.M. (1995). Mistakes were made in Organizations, apologia, and crises of social legitimacy. Communication Studies, 46(1-2), 1-17.

Hendriksen, E.S. (1982). Accounting theory. Homewood Illinois: Irwin.

Homayoun, S., \& Rahman, R. A. (2010).Determinants of web-based corporate reporting among top public listed companies in Malaysia. International Journal of Arts and Sciences, $3(13), 187-212$.

Hope, O. K. (2003a). Disclosure practices, enforcement of accounting standards an analysts' forecast accuracy: An international study. Journal of Accounting Research, 41(2), 235-272.

Iatridis, G. (2008). Accounting disclosure and firms' financial attributes: Evidence from the UK stock market. International Review of Financial Analysis, 17(2), 219-241.

Ibrahim, L. (2014). Accounting information disclosure by selected Nigerian deposit money banks, Unpublished Master's Dissertation. Usmanu Danfodiyo University, Sokoto, Nigeria.

Inchausti, B. G. (1997). The influence of company characteristics and accounting regulation on information disclosed by Spanish firms. The European Accounting Review, 6(1), 45-68.

Jensen, M. C. (1983). The modern industrial revolution, exit and the failure of internal control systems. The Journal of Finance, 48(3), 831-880.

Jensen, M., \& Meckling, W. (1976). Theory of the firm: Managerial behaviour, agency costs and ownership structure. Journal of Financial Economics, October, 305-360.

Kantudu, A. S. (2006). Application of Accounting Standards on Employee Retirement Benefits by Quoted Firms in Nigeria, Unpublished Doctoral Thesis. Amadu Bello University, Zaria, Nigeria.

Karim, A.K.M.W., Islam, A., \& Chowdhury, A. (1998). Financial reporting in Bangladesh: The regulatory framework. Journal of Business Administration, 24(1 \& 2), 57-88.

Khor, A.K.H. (2003). Social contract theory, legitimacy theory and corporate social and environmental disclosure policies: constructing a theoretical framework. Unpublished Working Waper, Nottingham University Business School.

Kiyanga, B. P. L. (2014). Corporate disclosure quality: A comparative study of Botswana and South Africa. Unpublished Master's Thesis, University of South Africa.

Lopes, P.T., \& Rodrigues, L.L. (2007). Accounting for financial instruments: An analysis of the determinants of disclosure in the Portuguese Stock Exchange. International Journal of Accounting, 42, 25-56.

Lu, H. (2009). Does disclosure of non-financial statement information reduce firms' propensity to under-invest? Unpublished Doctoral Thesis, University of Florida, USA.

Lunawat, R. (2010). Reputation effects of disclosure. Unpublished Doctoral Thesis, University of Minnesota, USA. 


\section{Mll Macrothink}

International Journal of Accounting and Financial Reporting

ISSN 2162-3082

2018, Vol. 8, No. 3

Madi, H. K., Ishak, Z., \& Manaf, N.A.A. (2014). The impact of audit committee characteristics on corporate voluntary disclosure. Procededia - Social and Behavioral Sciences, 164, 486-492.

McNally, G. M., Eng, L.H., \& Hasseldine, C.R. (1982). Corporate financial reporting in New Zealand: An Analysis of user preferences, corporate characteristics and disclosure practices for discretionary information. Accounting and Business Research, 13(48), 11-20.

Meek, G. K., \& Gray, S J (1989). Globalization of stock markets and foreign listing requirements: voluntary disclosures by continental European companies listed on the London stock exchange. Journal of International Business Studies, 20(2), 315-336.

Meek, G.C., Roberts, B., \& Gray, J. (1995). Factors influencing voluntary annual report disclosures by U.S., U.K. and Continental European multinational corporations. Journal of International Business Studies, 26(3), 555-572.

Moore, L., \& Buzby, S. (1972, July). The quality of corporate financial disclosure: A comment. Accounting Review, 581-584.

Naser, K., \& Al-Khatib, K. (2000). Determinants of the depth of voluntary disclosure in the directors statement in a sample of Jordanian listed companies'. Advanced in International Accounting, 13, 99-118.

Naser, K., \& Nuseibeh, R. (2003). Quality of financial reporting: Evidence from the listed Saudi nonfinancial companies. The International Journal of Accounting, 38(1), 41-69.

Naser, K., Al-Khatib, K., \& Karbhari, Y. (2002). Empirical evidence on the depth of corporate information disclosure in developing countries: The Case of Jordan. International Journal of Commerce and Management, 12(3-4), 122-155.

Ofoegbu, G., \& Okoye, E. (2006). The relevance of accounting and auditing Standards in corporate financial reporting in Nigeria: Emphasis on compliance. The Nigerian Accountant, 39(4), 45-53.

Okike, E.N.M. (2000). Extension of information in accounting reports: An investigation. Nigerian Financial Review, 3(2).

Omran, M., \& El-Galfy, A.M. (2014). The theoretical perspective on corporate disclosure: A critical evaluation and literature survey. European Journal of Marketing, 8(4), 257-286.

Owusu-Ansah, S. (1998b). The impact of corporate attributes on the extent of mandatory disclosures and reporting by listed companies in Zimbabwe. The International Journal of Accounting, 33(5), 603-631.

Popova, T., Georgakopoulos, G., Sotiropoulos, I., \& Vasileiou, Z.V. (2013). Mandatory disclosure and its impact on the company value. International Business Research, 6(5), 1-16.

Sarpong, K.K. (1999). Financial reporting in emerging capital markets: A case study of Ghana. Doctoral Thesis, University of Warwick, Coventry. Retrieved from http://go.warwick.ac.uk/wrap 


\section{Macrothink}

International Journal of Accounting and Financial Reporting ISSN 2162-3082 2018, Vol. 8, No. 3

Schipper, K. (2007).Required disclosures in financial reports. The Accounting Review, 82(2), 301-326.

Sethi, S.P. (1979). Advocacy advertising, and large corporations. Lexington: Lexington Books.

Singhvi, S.S. (1968). Corporate disclosure through annual reports in the United States of America and India. The Journal of Finance, 23(3), 551-552.

Singhvi, S.S., \& Desai, H.B. (1971). An empirical analysis of the quality of corporate financial disclosure. The Accounting Review, 46(1), 129-138.

Sternberg, E. (1997). The defects of stakeholder theory. Scholarly Research Theory Papers, 5(1), 3-10.

Street, D.L., \& Gray, S. J. (2001). Observance of international accounting standards: factor explaining non-compliance by companies referring to the use of IAS, ACCA. Research Monograph, 47, London.

Tilling, M.V. (2008). Refinements to legitimacy theory, social and environmental accounting. Flinders University, South Australia Conference Research Paper Series, Nr. 4-6.

Umoren A. O., \& Peace, O. (2011). Corporate governance, company attributes and voluntary disclosures: A study of Nigerian listed companies. International Journal of Research in Computer Application and Management, 1(2), 1-16.

Umoren, A.O. (2009). Accounting Disclosures and Corporate Attributes. Unpublished Doctoral Thesis, Covenant University, Ota, Nigeria.

Uwuigbe, U. (2011). An empirical investigation of the association between firms' characteristics and corporate social disclosures in the Nigerian financial Sector. Journal of Sustainable Development in Africa, 13(1), 61-80.

Van Der Laan, G. (2009). Behavioral Corporate Governance: Four Empirical Studies. The Netherlands: Print Partners Ipskamp BV, Enschede.

Wallace, R.S.O. (1987). Disclosure of Accounting Information in Developing Countries: A Case Study of Nigeria. Unpublished Doctoral Thesis, University of Exeter, UK.

Wallace, R.S.O., Naser, K., \& Mora, A. (1994). The relationship between the comprehensiveness of corporate annual reports and firm characteristics in Spain. Accounting and Business Research, 25(97), 41-53.

Wartick, S. L., \& Mahon, J.F. (1994). Toward a substantive definition of the corporate issue construct. Business and Society, 33(3), 293-311.

Watson, A., Shrives, P., \& Marston, C. (2002). Voluntary disclosure of accounting ratios in the UK. British Accounting Review, 34(4), 289-313.

Watts, R. L., \& Zimmerman, J. L. (1986). Positive accounting theory. Englewood Cliffs, NJ: Prentice-Hall 


\section{Macrothink}

International Journal of Accounting and Financial Reporting ISSN 2162-3082 2018, Vol. 8, No. 3

Wolk, H.I., Dodd, J.L., \& Rozycki, J.J. (2008). Accounting theory. Thousand Oaks, California: Sage.

Woodward, D.G. (1993, November). A stakeholder approach to corporate social reporting analysis. Sheffield University Management School Discussion Paper No 93.39. Sheffield University.

Xiao, Y. (1999). Corporate disclosures made by Chinese listed companies. The International Journal of Accounting, 34(3), 349-373.

\section{Copyright Disclaimer}

Copyright for this article is retained by the author(s), with first publication rights granted to the journal.

This is an open-access article distributed under the terms and conditions of the Creative Commons Attribution license (http://creativecommons.org/licenses/by/4.0/) 